\title{
Translation of a Selection of Poems by Caitlín Maude and Mary O'Malley into Spanish
}

\author{
Pura López Colomé (Introduction) \\ Enrique Alda (Translation)
}

Copyright (ㅇ 2019 by Pura López Colomé and Enrique Alda. This text may be archived and redistributed both in electronic form and in hard copy, provided that the author and journal are properly cited and no fee is charged for access.

\section{Introduction. On Enrique Alda's versions}

Upon reading Seamus Heaney's early poetry collections - and this was a long time ago - I was surprised by his subtle way of offering up his own versions of poems by other authors as a way to making them his own and moulding them with exacting precision into the specific theme of each given collection. Rather than referring to them as "translations", he used the word after as an antecedent (to works by the likes of Dante, Baudelaire, Virgil, and some Gaelic authors) with the aim of reworking them into newly inspired viewpoints a posteriori; thus, the poem's metaphors and images, initially belonging to a different language, would be born again, this time to a different voice and melody - his own - in such a way that his harmonious yet elusive "music of events" was crafted into something visible and audible. I owe this great Captain the sudden epiphany of conceiving translation as creation, as an opportunity of feeding foreign sounds to a symphony of musical inimitability. As time went on, I had the chance to be present at some of his poetry readings, attended by audiences of varying sizes, where - to put it this way - "the yellow bittern", otherwise known as the seventeenth-century "An Bunnán Bui", would take flight in yet another twentieth-century poem by Heaney.

The Irish tradition is fortunate enough to host poet-translators whose bilingual output has been fostered by the co-existence of two languages: these authors write in what they feel to be their mother tongue, and then harken back to their second language. While those of us who live under different linguistic circumstances come across this realization in alternative ways, considering this background there is no room for doubt that the person wishing to render a poem into a different language must necessarily be a poet, or else should have experienced first-hand the implications of writing without colliding against semantic plurality. This poet-translator may have never published their poems; however, he or she has written them into existence, even if privately and far from the gaze of discerning eyes, or will do so in the future. Deep down, nevertheless, this poet must firmly believe that "translating" poetry is far from being a mere task of chancing upon perfect equivalents. It is precisely in this light that renowned poet Anne Carson defines as synonymy the realtionship between poetry and translation, even if one is faced with muttering or complete silence. After all, absolute ownership of a poem has grown to matter less and less now that we have come to understand Homer as a conglomerate of poets rather than an individual entity.

Enrique Alda's translations of Caitlín Maude (1941-1982) and Mary O’Malley - the former being an excellent example of the Gaelic-English-Spanish triangle and the latter's poetry in English likewise dancing to vibrant Gaelic rhythms - are Greek in their approach: 
that is, they see language as the veil under which the truth of all things shines away, and poetry as the revealing rip in the fabric elaborated by the individual language in question. The intense flow of his versions immediately catches the eye, in a way which recalls the literary compulsion of the naturally risk-taking poet, rather than the careful craftsman. His achievements remind one of Borges's perceptions on translation: "Translations are far from being inferior to the original, but we must necessarily perceive a difference between them ... which is not within the reach of the translator; rather, it lies in the way poetry is read".

Both poets owe themselves to Connemara, by which I mean that each utilizes her own style to replicate the deep rhythms and tonalities of the regional voice. While Maude's poetry stems from the Gaelic language, O'Malley's poetry is in English, which bridges both poets with Enrique Alda's language.

Caitlín Maude's versions (not the originals) have been put forth by a variety of authors intent on paying tribute to her genuine way of singing in the dark (in the corner of a room, or the darkness underneath the speaker's closed eyes) and the quiet summoning of readers or listeners willing to participate. Translators into English such as Trodden Keefe, Fitzmaurice, Hartnett and Ní Chonchúir show the necessity to emulate the brief and mostly nasal pauses, the long syllables at the end of sentences, the glissandos, and even the endings struggling to be spoken rather than sung - in itself a trait of ancient a cappella singing. Enrique is aware of the incapacity of the Spanish language to achieve that effect. He decides, therefore, to bestow his poetic enterprise with precise originality through the use of careful repetitions and impeccably flawless Castilian cadences; he never loses sight of the translator's task of contributing something beyond the original version, an outcome in turn to be desired from an artistic point of view, as Walter Benjamin and George Steiner have noted. The titles he chooses exceed mere literalism ("Tangled" is "Maraña"; "Interval" becomes "Arrebato"; "Entreaty" is translated into "Súplica", to mentioned but a few), thus instating a rigorous identification between meaning and content which he later sends to multiple directions and ends with his own personal touch in the form of a risky addendum. Let me briefly sample the poem "Maraña", which might as well have been composed in our own language. So faultlessly does the musicality of the final lines strengthen the original meaning that the protagonist/speaker feels compelled to actively - rather than passively - descend, wander out, and be swallowed whole by the depths of sorrow and loneliness: "Pasea esta noche por la playa,/mi amor,/ pasea y detén tus lágrimas,/ levántate y pasea esta noche,/no te arrodilles más/ante esa tumba en la montaña,/sus flores están marchitas/y mis huesos descompuestos.../esta noche te llamo/desde las profundidades del océano..../Una vez recorrí la orilla/hasta el final de la playa,/donde las olas jugaban/y la blanca espuma besaba mis pies./Inundando lentamente mi mirada/allí, en lo más profundo,/en la maraña de olas y espuma,/vi la soledad en tus ojos/y la pena en tu rostro".

These are both the original and Alda's solution to the ending of the poem:

"I wandered out in the depths/From knees to waist/And from waist to shoulders/Until I was swallowed/In sorrow and loneliness".

"Descendí hasta las profundidades/de la rodilla a la cintura/y de la cintura a los hombros, /hasta que me hundí/en la soledad y la pena".

It is likely that the spiritual direction of this song of love and lament has influenced the translator's choice of a well-defined musicality, which is evidenced in the speaker's desire to actually sink. 
In the case of Mary O'Malley, Enrique's approach unearths further nuances of meaning and, as I see it, seeks to identify himself with the voice of the female through the reverberation of an intimate, private, and womanly speech, one which reaches out to its echo in the world. This time, poetic music does not lead the way; instead, it is the author's voice whose particularly opaque elevation is painted with a religious, historical, mythological and legendary veneer and, as such, is not necessarily melodious - that weaves together landscape and word, place and syllable, home and consonants, brusque, loss-inducing, rupture-sounding silences and traditional moulds which have long lost their arbitrariness. The emotions of the natural world are brought to life in Spanish through the names of flowers and the most minute details of humans and animals, encapsulating both into a destiny which, far from being always entirely happy, is oftentimes cruel. I can earnestly say that in Alda's versions I do not search for the leftovers of poetic English: I am captivated by his symbols in Spanish of a present time blended into a continuous past: "Lo sabe por los caballos/ parados en todas partes/en los campos, la mirada/fluida como versos,/dejados de lado durante años/junto al rosario y las oraciones/pero abundantes de nuevo/como prímulas o aulagas;/por el sucinto temblor en su $\mathrm{piel} / \mathrm{sabe}$ que escuchan/las noticias que atañen/nuestro destino y el suyo".

A distinguished translation of poetry can come exceedingly close to the original. It can let death abandon the pile of worn-out topics and come to the fore (in, as Enrique phrases it, "las voces atrapadas de los ahogados/ o el extraño grito de criaturas mudas/que anhelan algo más,/ser humanas"). It can make sure that speaking a language or not does not guarantee anything, thereby letting us prove that languages are not commanded. That poetry transcends all this.

Pura López Colomé

(Translated into English by Germán Asensio Peral)

\section{A note by the editor}

Every effort has been made to trace copyright holders and to obtain their permission for the use of copyright material. The editor apologizes for any errors or omissions and would be grateful if notified of any corrections that should be incorporated in this year's issue of Estudios Irlandeses. 


\title{
Poems by Caitlín Maude
}

\author{
Aimhréidhe \\ Siúil, a ghrá, \\ Cois trá anocht - \\ Siúil agus cuir uait \\ na deora - \\ éirigh agus siúil anocht \\ ná feac do ghlúin feasta \\ ag uaigh sin an tsléibhe - \\ tá na blátha sin feoite \\ agus tá mo chnámhasa dreoite... \\ (Labhraim leat anocht \\ ó íochtar mara - \\ labhraim leat gach oíche \\ ó íochtar mara...) \\ Shiúileas lá cois trá \\ shiúileas go híochtar trá - \\ rinne tonn súgradh le tonn - \\ ligh an cúr bán mo chosa - \\ d'ardaíos mo shúil go mall \\ gur ansiúd amuigh ar an domhain \\ in aimhréidhe cúir agus toinn \\ chonaic an t-uaigneas id shúil \\ 'gus an doilíos id ghunúis \\ Shiúileas amach ar an domhain \\ ó ghlúine go com \\ agus ó chom go guaillí \\ nó gur slogadh mé \\ sa doilíos gus san uaigneas
}

TANGLED MARAÑA

Wander, my love along the shore tonight wander and stop your weeping rise up and wander tonight bend your knees no more at that mountain grave Pasea esta noche por la playa mi amor pasea y detén tus lágrimas, levántate y pasea esta noche, no te arrodilles más ante esa tumba en la montaña, sus flores están marchitas 
those flowers are wihtered and my bones are mouldering... I speak to you tonight from sea-depth I speak to you every night from sea depth...

I once wandered along the shore I wandered to shore-end wave made game with wave white foam licked my feet slowly seeping into my vision there out in the depths in the tangle of foam and wave I saw the loneliness in your eyes and the sorrow in your face

I wandered out in the depths from knees to waist and from waist to shoulders until I was swallowed in sorrow and loneliness

(Trans. Joan Trodden Keefe) y mis huesos descompuestos... esta noche te llamo desde las profundidades del océano todas las noches te llamo desde las profundidades del océano...

una vez recorrí la orilla hasta el final de la playa, donde las olas jugaban y la blanca espuma besaba mis pies. Inundando lentamente mi mirada allí, en lo más profundo, en la maraña de olas y espuma, vi la soledad en tus ojos y la pena en tu rostro.

descendí hasta las profundidades de la rodilla a la cintura y de la cintura a los hombros, hasta que me hundí en la soledad y la pena.
Impí

A ógánaigh, ná tar i mo dháil, ná labhair... is binn iad briathra grá is binne aríst an friotal nár dúradh ariamh níl breith gan smál breith briathar amhlaidh atá is ní bheadh ann ach 'rogha an dá dhíogh'

ó tharla an scéal mar 'tá... ná bris an ghloine ghlan 'tá eadrainn (ní bristear gloine gan fuil is pian) óir tá Neamh 


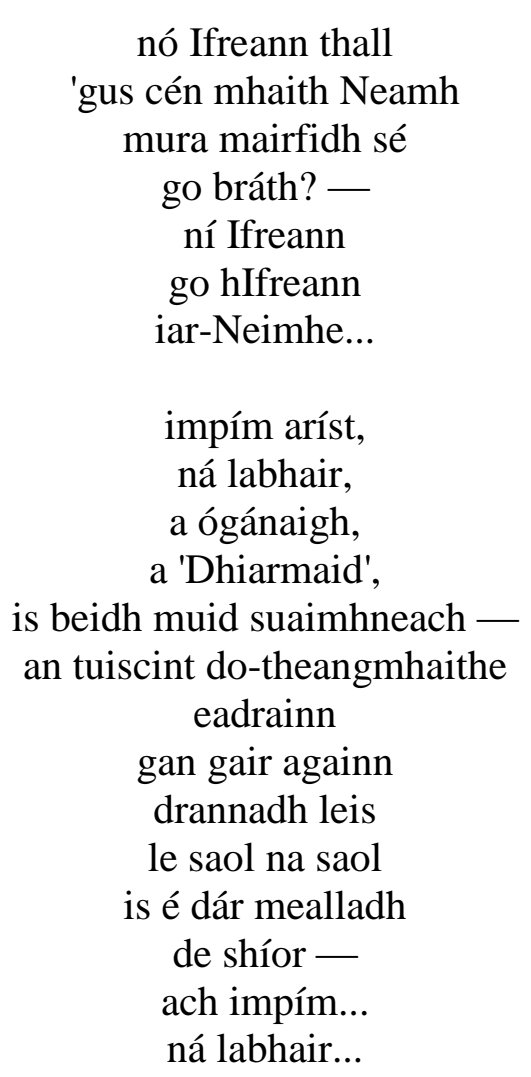

ENTREATY

SÚPLICA

Young man,

do not come near me,

do not speak...

the words of love

are sweet -

but sweeter still

is the word

that was never uttered -

no choice

is without stain -

the choice of words

is much the same

and this would be

to choose between evils

in our present

situation...

Do not break

the clear glass

between us

(no glass is broken

without blood and pain)

for beyond is Heaven

or beyond is Hell

and what good is Heaven
Joven

no te acerques

no hables...

dulces son

las palabras de amor

pero más dulce es aún

la palabra no pronunciada

ninguna elección carece de mácula,

ni siquiera con las palabras,

elegirlas en esta situación

sería decidir entre la espada y la pared...

no rompas

el diáfano cristal

que nos separa

(ninguno se quiebra

sin sangre y dolor)

al otro lado se hallan

el cielo o el infierno

y ¿de qué sirve el cielo

si no es eterno?

no hay peor infierno

que haber conocido el cielo...

de nuevo, te lo imploro 
if it is not

for ever? -

the loss of

Heaven

is the worst Hell...

I again implore you,

do not speak,

young man,

my "Diarmaid",

and we will be at peace -

untouchable understanding

between us

we will have no cause

to touch it

ever

as it ever

allures us -

but I implore you...

do not speak...

(Trans. Gabriel Fitzmaurice) no hables

mi Diarmaid

y tendremos paz,

nunca habrá necesidad de tocar

ese entendimiento intangible

entre nosotros

que siempre nos tienta

pero, te lo ruego,

no hables...

\author{
Lá amháin \\ Lá amháin \\ bhí an clóscríobhaí tinn - \\ bhí ar stiúrthóir an chomhlachta \\ an clóscríobhán \\ a thabhairt isteach \\ ina oifig féin \\ chuir na litreacha \\ an oiread déistin air \\ gur stróic sé iad \\ 'gus gur scríobh sé dán \\ tamall ina dhiaidh \\ d'éirigh sé as a phost \\ 'gus ina dhiaidh sin \\ a theach \\ a bhean \\ agus a chlann \\ agus anois \\ tá sé ina fhile \\ an fear bocht
}


One day

the typist was sick

the company director

had to take the typewriter

into his office

the letters

so disgusted him

that he tore them up

and wrote a poem

shortly after that

he left his job

and after that

his house

his wife

his kids

and now he's a poet

the poor fucker.
Un día

la mecanógrafa se puso enferma

el director de la empresa

tuvo que llevar la máquina de escribir

a su despacho

las cartas

le desagradaron tanto

que las rompió

y escribió un poema

poco después

dejó el trabajo

y más tarde

dejó su casa

a su mujer

y a su familia

ahora es poeta,

el pobre idiota.

(Trans. Michael Hartnett)

Tá sé in am dán deiridh a scríobh

Tá sé in am dán deiridh a scríobh.

dán mar 'bheadh inneall nua-aoiseach den scoth a bhfuil chuile smaoineamh i dtaisce ina chroí. dán mar 'bheadh leabhar

nach gá a léamh

mar 'bheadh foclóir

aon leathanaigh

aon teangan

mar 'bheadh pictiúr

Ghairdín Pharrthais th'éis pheaca Éabh'.

dán teilifíse le nuacht an lae

dán a bhrisfeas do chroí

blaosc uibhe do chroí

ar an toirt

dán a bhfuil muirín fhada air

na mílte dánta beaga gleoite

ar imeall an phictiúir 
dánta grá 'le fíormhothúchán'

dán siopa $29 / 11$
dán tourists

a thugann aicídeacha teochreasacha leo agus airgead

a thugann drochsmaointe don easpag

a chaitheann seanmóir bhreise a scríobh don deoise

lena choinsias a ghlanadh

dán galánta

dán leathghalánta

ciomach de dhán

\section{IT'S TIME TO WriTE A POEM}

It's time to write a poem

a poem like the best most modern machine every thought stored up inside it

a poem like a book

one need not read

like a dictionary

with one page

with one language

like a picture

of Paradise after Eve's sin

a telly-poem with daily news

a poem to break your heart

your eggshell heart

your egg of putty heart

on the spot

a longtailed poem

thousands of pretty poemlets

at the edge of the picture

a love poem "with true emotion"

a shop poem $29 / 11$

a poem for tourists

that gives them tropical diseases

and money

that gives bad thoughts to the bishop

who has to write an extra sermon for the diocese

a stylish poem

a half-stylish poem

a slut of a poem
Es HorA De EsCRIBIR Un POEMA

Es hora de escribir un poema

un poema que sea la mejor de las máquinas modernas que almacene todos los pensamientos

un poema semejante a un libro

que no es necesario leer,

a un diccionario

de una página

y un idioma,

a una imagen

del paraíso después del pecado de Eva

un poema telediario

un poema que te rompa el corazón

la delicada cáscara de tu corazón

tu corazón maleable

al instante

un poema que traiga cola

miles de bonitos poemitas

al borde de la imagen

un poema de amor «con verdadera emoción»

un poema comercial un año y un día

un poema para turistas

que les transmita enfermedades tropicales

y dinero

que inspire malos pensamientos al obispo

y le obligue a escribir un sermón más para la diócesis

un poema elegante

un poema medio elegante

un poema puta

un poema para mujeres y niños 
a poem for women and children a totally useless poem

poem

litany

poem.

(Trans. Michael Hartnett)

\author{
un poema totalmente inútil \\ poema \\ letanía \\ poema
}

\author{
Treall \\ Tabhair dom casúr \\ nó tua \\ go mbrisfead is \\ go millfead \\ an teach seo, \\ go ndéanfad tairseach \\ den fhardoras \\ 'gus urláir de na ballaí, \\ go dtiocfaidh scraith \\ agus díon agus \\ simléir anuas \\ le neart mo chuid \\ allais... \\ Sín chugam anois \\ na cláir is na tairní \\ go dtóigfead \\ an teach eile seo...
}

Ach, a Dhia, táim tuirseach!

INTERVAL

Hand me a hammer

or a hatchet

to demolish and

to smash

this house,

to make a threshold

of the lintel

and floors of the walls,

so that the scraws and roof and

chimney are razed

with the force of my

sweat...

Now hand me

the planks and the nails

so that I can build
ARREBATO

Dame un martillo

o un hacha

para derribar y

hacer pedazos

esta casa,

para crear un umbral

con el dintel

y suelos con las paredes,

para desmantelar

la techumbre de turba

y la chimenea

con el sudor de mi frente...

Ahora, dame

tablas y clavos

para construir

otra casa... 
this other house...

But, my God, I'm tired!

Pero, ¡Dios mío!, estoy tan cansada...

(Trans. Nuala Ní Chonchúir)

Na blátha

Chuas amach an mhaidin sin

i mo pháiste

folaithe, do-ghonta -

tháinigeas isteach

i mo dhuine fásta

m'anam nocht feannta -

céadbhlátha an earraigh

- blátha buí - sláimín,

i lár an ghairdín -

ní raibh ann

ach ala gan chomhaireamh

inar bhlaiseas

rud éicint

nár den tsaol seo

inar cuireadh

ó aithne

orm féin mé

gur thuigeas

go rabhas leonta

le lann na háille -

lann ar a hainm

le glaine

le géire

níor bhlátha na blátha

ach beos

áille agus céasadh.

THE FLOWERS

I went out that morning

a child

unaware, invulnerable -

I returned

an adult

my soul bared, flayed -

\section{LAS FLORES}

Aquella mañana salí siendo una niña inconsciente, invulnerable

Regresé

adulta

con el alma desnuda, desollada 
spring's first flowers - tufted buttery blooms, standing in the garden -

it was only

a passing moment

in which I tasted

something

otherworldly

in which I

was pulled

out of myself

to understand

that I'd been wounded

by beauty's blade -

beauty's name made

clean

keen

these flowers were not just flowers

but life

beauty and torment.

(Trans. Nuala Ní Chonchúir)

\section{Poems by Mary O’Malley}

NEWS

He knows by the horses

that are everywhere in the fields

unemployed, their gaze

fluent as verses,

put aside for years

with the rosary beads and prayers

but lately plentiful again

as primroses or furze;

by the quick shivers of their skin he knows they are listening

to news that concerns las primeras flores de primavera, ramilletes de brotes dorados, nacían en el jardín

fue un instante fugaz en el que percibí algo sobrenatural, en el que despojada de mí misma comprendí que me había herido el filo de la belleza

y su nombre se reveló puro nítido

no eran simples flores, sino vida belleza y tormento
Noticias

Lo sabe por los caballos parados en todas partes

en los campos, la mirada fluida como versos,

dejados de lado durante años junto al rosario y las oraciones

pero abundantes de nuevo como prímulas o aulagas;

por el sucinto temblor en su piel sabe que escuchan

las noticias que atañen 
our fate and theirs.

\section{Space Time Curve}

He was my knife then.

There were flashes

Of steel in the sun.

He cut an orange into quarters

and handed me one,

the blade sweet with juice.

That's how it was in the sun,

Strawberries for lunch and a swim

Into life itself. Life tastes

Of salt and strawberries

And the flat lick of steel

Then the sting of a thorn in your heel

When time swerves and curls

Backwards and we're poised

at the top of a wave all unfurled

The girl, the fruit and the man

With the knife in his hand.

\section{GOLDFINCHES}

Who can believe that God plays dice and make a way through life?

A foot from the window a cloud

Of goldfinches descend on the niger seed.

Nothing I have done merits this charm their cat faces yellow and red, as if

exotic flowers had taken to the air transformed and came here

to Seanbhaile, Maigh Cuilinn, the world our egocentric sun revolves around

as Shakespeare saw the sun spin around the earth because we all cling

when all the Gods are banished down to Saturn or Pandemonium

to a steady planet with a friendly sun circling around us, even Einstein. nuestro destino y el suyo.

\section{ESPACIO TIEMPO CURVA}

Entonces era mi cuchillo.

Destellos de acero

en el sol.

Cortó una naranja en cuatro trozos

y me ofreció uno,

la hoja empapada en dulce zumo.

Así era en el sol,

fresas para comer y un baño

en la vida misma. La vida sabe

a sal y fresas

a lamer la hoja de acero,

después, una espina en el pie.

Cuando el tiempo vira y se encrespa

hacia atrás y estamos suspendidos

en lo alto de una ola desplegada

la joven, la fruta y el hombre

con el cuchillo en la mano.

\section{JILGUEROS}

¿Quién cree que Dios juega a los dados y sigue su camino?

A un palmo de la ventana, un tropel

de jilgueros desciende sobre las semillas de Níger.

Nada de lo que he hecho merece semejante encanto, caras de gato amarillas y rojas, como si

unas flores exóticas hubieran levantado el vuelo transformadas y llegado

a Seanbhaile, Maigh Cuilinn, al mundo en torno al que orbita nuestro egocéntrico sol

tal como lo vio girar Shakespeare

rodeando la Tierra, porque

cuando los dioses se destierran

a Saturno o el Pandemonio

todos nos aferramos

a un planeta inmóvil con un sol complaciente 
que da vueltas a nuestro alrededor, incluso Einstein.

\section{DESCENT}

I have looked for you among the Greeks Where hate and love are close as blood And blood is worth so much and no more

I went down among the Greeks reluctantly not trusting in cheap plunder but there is no more time. Threads have been pulled

time woven, knotted, snipped. I went to the cities and the far islands and met statues, women with blind eyes

and no mercy. In temples and bars and houses everywhere I saw your likeness, and everywhere women with their bored gaze

fixed beyond me, on some blue island with dolphins, an olive tree, the dangerous bull in his maze, and the woman who holds the thread.

None of them spoke to me, just one more Crazed mother searching for her daughter They are used to that here.

\section{VIGIL}

I have paid the coin time has extracted With another in my mouth for the shroud A willing deposit for when you are found.

I will stand in the helical stream with the winds Scorching my ankles until someone looks up And says 'Bargain' and then I will go down

To meet her and bring the small red Seeds of the sun to remind her of home. I will stand there until the dark breaks open.

\section{DESCENSO}

Te he buscado entre los griegos en los que el odio y el amor son cercanos como la sangre, y la sangre se valora, y nada más

Descendí entre los griegos a regañadientes sin confiar en el expolio fariseo, pero ya no hay tiempo. Se ha tirado de los hilos

el tiempo se ha tejido, anudado, cortado. Fui a las ciudades y las islas lejanas y encontré estatuas, mujeres con ojos ciegos

y despiadadas. En templos, en bares y casas, en todas partes vi tu semejanza, y en todas partes mujeres con mirada cansada

fija en la lejanía, en una isla azul con delfines y un olivo, el peligroso toro en su laberinto, y la mujer que sujeta el hilo.

Ninguna me habló, solo era otra madre desesperada buscando a su hija Allí están acostumbradas.

\section{VIGILIA}

He pagado la moneda que el tiempo me ha extraído en mi boca hay otra para el sudario un pago voluntario para cuando te encuentren.

Permaneceré en la corriente helicoidal y los vientos me abrasarán los tobillos, hasta que alguien mire y diga «trato hecho», entonces me hundiré

para reunirme con ella y llevarle las semillas rojas del sol que le recuerden su hogar. Permaneceré allí hasta que quiebre la oscuridad 
Pura López Colomé is a Mexican poet, translator and literary critic. Twelve of her poetry collections have been published under the title Poemas reunidos 1985-2012. Her latest book of poems is Via Corporis (Fondo de Cultura Económica, 2016). She has translated several of Seamus Heaney's works, collected in the bilingual edition Obra Reunida (Conaculta, 2015). Among the literary honors she has received are Premio Xavier Villaurrutia (poetry), Premio Nacional Alfonso Reyes (essay), Premio Nacional de Traducción Literaria (for her translation of Heaney's Station Island). She lives in Cuernavaca, México.

pura.lopez.colome@gmail.com

Enrique Alda is a Spanish translator with a degree in Translation and Interpretation from the University of Salamanca and has been translating literature for more than twenty years. In the past ten years he has focused his work on Irish literature, especially on contemporary Irish women poets. In 2016 he was awarded the Marcelo Reyes Prize for translation. He lives in Ireland and divides his time between the sunny slopes of the Moncayo in Spain and the green fields of Wicklow.

ealda@ealda.com 